\title{
Is maize B chromosome preferential fertilization controlled by a single gene?
}

\author{
A. MAURICIO CHIAVARINO\$, MÓNICA GONZÁLEZ-SÁNCHEZ†', LIDIA POGGIO\$§, \\ MARÍA J. PUERTAS*†, MARCELA ROSATO $\$$ \& PABLO ROSI $\$ \S$ \\ $\dagger$ Departamento de Genética, Facultad de Biología, Universidad Complutense, 28040 Madrid, Spain, \\ $\$$ Instituto Fitotécnico de Santa Catalina (FCAF, UNLP)-Centro de Investigaciones Genéticas \\ (UNLP-CONICET-CIC), C.C. 41836 Llavallol, Buenos Aires, Argentina and §Departamento de Biología, \\ Facultad de Ciencias Exactas y Naturales, Universidad de Buenos Aires, 1428 Buenos Aires, Argentina
}

\begin{abstract}
In previous work, genotypes for high and low B chromosome transmission rate were selected from a native race of maize. It was demonstrated that the $\mathrm{B}$ transmission is genetically controlled. The present work reports the fourth and fifth generations of selection and the $\mathrm{F}_{1}$ hybrids between the lines. The native $\mathrm{B}$ is characterized by a constant behaviour, with normal meiosis and nondisjunction in $100 \%$ of postmeiotic mitosis. It is concluded that genetic variation for $\mathrm{B}$ transmission between the selected lines is due to the preferential fertilization process. The $F_{1}$ hybrids show intermediate $B$ transmission rate between the lines. They are uniform, the variance of the selected character being one order of magnitude lower than that of the native population. In addition, $0 \mathrm{~B} \times 2 \mathrm{~B}$ and $2 \mathrm{~B} \times 2 \mathrm{~B}$ crosses were made to study the effect of the presence of $\mathrm{B}$ chromosomes in the female parent, resulting in non-significant differences. Several crosses were made both in Buenos Aires and in Madrid to compare the possible environmental effect, but significant differences were not found. Our results are consistent with the hypothesis of a single major gene controlling B transmission rate in maize, which acts in the egg cell at the haploid level during fertilization. It is also hypothesized that maize Bs use the normal maize fertilization process to promote their own transmission.
\end{abstract}

Keywords: B-chromosomes, maize, preferential fertilization, Zea mays.

\section{Introduction}

The numerical polymorphism for the B chromosomes (Bs) of maize is maintained by three main processes: (i) B nondisjunction at the second pollen grain mitosis, which produces sperm nuclei with different B numbers (Roman, 1947; Carlson, 1978; Carlson \& Chou, 1981); (ii) preferential fertilization by the sperm nucleus carrying the Bs after the nondisjunction process (Roman, 1948; Carlson, 1969); and (iii) the suppression of meiotic loss when the Bs are unpaired (Carlson \& Roseman, 1992).

Beckett (1982) proposed a higher competitive ability of B-carrying pollen grains as an additional mechanism to maintain the Bs in maize. However, Carlson (1997) reported results that do not show a clear advantage of B-carrying pollen over normal pollen.

Most of these features and other properties of maize Bs have been studied taking advantage of lines carrying reciprocal translocations between the Bs and chromo-

*Correspondence. E-mail: majetas@eucmax.sim.ucm.es somes of the normal set (A chromosomes, As). The A fragment of the $\mathrm{B}^{\mathrm{A}}$ chromosome carries genetic markers which reveal the presence of the B. In this way, tedious cytological screening for the Bs is unnecessary. Consequently, maize native Bs are poorly known at the population level.

In 1993 a selection process was initiated to study the cytological features and the genetic control of maize B transmission in the native race Pisingallo from Argentina, where the Bs are present in $44 \%$ of the individuals. It was demonstrated that $\mathrm{B}$ transmission rate (B-TR) is genetically controlled, both on the female and male sides, and genotypes were isolated that control high $(\mathrm{H})$ and low (L) B-TR (Rosato et al., 1996). It was later demonstrated that the genes controlling male B-TR are located on the A chromosomes, because in female $0 \mathrm{~B} \times$ male $2 \mathrm{~B}$ crosses, the $\mathrm{B}-\mathrm{TR}$ depends on the $\mathrm{H}$ or $\mathrm{L}$ status of the 0B female parent (Chiavarino et al., 1998). The results of that work also showed that preferential fertilization by the 2B-carrying sperm nucleus does not always occur, so that in $0 \mathrm{~B}$ female parents of the $\mathrm{H}$ genotype the frequency of fertilization by the $2 \mathrm{~B}$ sperm 
is increased, but in the L genotype fertilization by the $0 \mathrm{~B}$ or $2 \mathrm{~B}$ sperm nucleus is at random, resulting in a Mendelian B-TR.

The present work reports the results of the fourth and fifth generations of selection (G4 and G5) for $\mathrm{H}$ and $\mathrm{L}$ male B-TR. We report the behaviour of the HL and $\mathrm{LH}$ $\mathrm{F}_{1}$ hybrids. In addition, $\mathrm{OB} \times 2 \mathrm{~B}$ and $2 \mathrm{~B} \times 2 \mathrm{~B}$ crosses were made to study the effect of the presence of $\mathrm{B}$ chromosomes in the female parent on male B-TR. Several of these crosses were made both in Spain and Argentina to study possible environmental effects.

\section{Materials and methods}

The materials used were selected lines of maize, Zea mays ssp. mays. The lines were obtained from crosses female $0 \mathrm{~B} \times$ male $2 \mathrm{~B}$, whose progeny was selected for high and low $\mathrm{B}$ transmission rate during five generations. These lines were actually selected for $\mathrm{H}$ or L male B-TR because the Bs were always transmitted on the male side. The selection process was carried out following the method described in Rosato et al. (1996) and in Chiavarino et al. (1998). The original material, from which the selection was initiated, belongs to the native race Pisingallo from NW Argentina (Rosato et al., 1998).

In all crosses mentioned in the following, the female parent will be indicated first; for example, a $0 \mathrm{~B} \times 2 \mathrm{~B}$ cross means that the female parent had $0 \mathrm{~B}$ and the male parent had 2B. Similarly, an HL hybrid is that obtained using a plant of the $\mathrm{H}$ line as female and a plant of the $\mathrm{L}$ line as male.

We used the following genotypes and crosses:

$10 \mathrm{~B}$ and $2 \mathrm{~B}$ plants of the third and fourth generation of selection for high $\mathrm{B}-\mathrm{TR}$ in $0 \mathrm{~B} \mathrm{H} \times 2 \mathrm{~B} \mathrm{H}$ crosses, were used to make both $0 \mathrm{~B} \mathrm{H} \times 2 \mathrm{~B} \mathrm{H}$ (which correspond to the fourth and fifth generation of selection, respectively) and $2 \mathrm{~B} \mathrm{H} \times 2 \mathrm{~B} \mathrm{H}$ crosses.

2 The same as in $\mathbf{1}$ but using the $\mathrm{L}$ line.
$30 \mathrm{~B}$ and $2 \mathrm{~B}$ plants obtained from $0 \mathrm{~B} \mathrm{H} \times 2 \mathrm{~B}$ L crosses, that we call HL hybrids, were used to make both $0 \mathrm{~B} \mathrm{HL} \times 2 \mathrm{~B} \mathrm{HL}$ and $2 \mathrm{~B} \mathrm{HL} \times 2 \mathrm{~B} \mathrm{HL}$ crosses.

$40 \mathrm{~B}$ and $2 \mathrm{~B}$ plants obtained from $0 \mathrm{~B} \mathrm{~L} \times 2 \mathrm{~B} \mathrm{H}$ crosses, that we call $\mathrm{LH}$ hybrids, were used to make both $0 \mathrm{~B} \mathrm{LH} \times 2 \mathrm{~B} \mathrm{LH}$ and $2 \mathrm{~B} \mathrm{LH} \times 2 \mathrm{~B} \mathrm{LH}$ crosses.

The crosses described in $\mathbf{1}$ and $\mathbf{2}$ were made both in Buenos Aires (Argentina) and Madrid (Spain). Crosses described in $\mathbf{3}$ and $\mathbf{4}$ were made in Madrid. In Buenos Aires the plants were grown in the greenhouse of the IFSC (Universidad Nacional de La Plata) whereas in Madrid the plants grew outside, in the experimental field of the Complutense University.

To score for $\mathrm{B}$ chromosome number, the primary root tips were pretreated with $0.002 \mathrm{~mol} / \mathrm{L}$ 8-hydroxyquinoline for $3 \mathrm{~h}$ at $20-22^{\circ} \mathrm{C}$, subsequently fixed in ethanol : acetic acid $3: 1$ and stained by the Feulgen method.

\section{Results}

Table 1 shows the results of the crosses made in Madrid. The progeny obtained in crosses $0 \mathrm{~B} \times 2 \mathrm{~B}$ allows deduction of the transmission of $\mathrm{B}$ chromosomes on the male side. Nearly all the progeny carried either 0 or 2 Bs indicating that nondisjunction occurred in $100 \%$ of the cases, because 1B plants were not found. Only one out of 640 plants $(0.16 \%)$ had $4 \mathrm{Bs}$, in all probability, by lack of proper segregation at meiosis followed by nondisjunction of both Bs. This low frequency of B transmission irregularities shows that in this native race the Bs have a remarkably constant behaviour at male meiosis and pollen mitosis, characterized by the segregation of the two Bs to opposite poles in more than $99 \%$ of the anaphase I cells and nondisjunction of the single $\mathrm{B}$ in $100 \%$ of postmeiotic mitoses.

Male $\mathrm{B}-\mathrm{TR}$ in $\mathrm{OB} \times 2 \mathrm{~B}$ crosses was estimated by dividing the number of B-carrying plants in the progeny

Table $1 \mathrm{~B}$ transmission in $0 \mathrm{~B} \times 2 \mathrm{~B}$ and $2 \mathrm{~B} \times 2 \mathrm{~B}$ maize crosses made in Madrid

\begin{tabular}{|c|c|c|c|c|c|c|c|c|c|c|c|}
\hline \multirow[b]{2}{*}{ Type of cross } & & \multirow{2}{*}{$\begin{array}{l}\text { No. of } \\
\text { crosses }\end{array}$} & \multicolumn{7}{|c|}{ No. of Bs in the progeny } & \multirow{2}{*}{$\begin{array}{l}\text { Mean male } \\
\mathrm{B}-\mathrm{TR} \pm \mathrm{SE}\end{array}$} & \multirow{2}{*}{$\begin{array}{c}\text { Unexpected } \\
\text { progeny } \\
(\text { mean } \pm \mathrm{SE})\end{array}$} \\
\hline & & & 0 & 1 & 2 & 3 & 4 & 5 & Total & & \\
\hline & $\mathrm{HL} \times \mathrm{HL}$ & 6 & 64 & & 94 & & & & 158 & $0.578 \pm 0.020$ & \\
\hline & $\mathrm{LH} \times \mathrm{LH}$ & 6 & 71 & & 86 & & & & 157 & $0.548 \pm 0.013$ & \\
\hline & $\mathrm{L} \times \mathrm{L}$ & 7 & 94 & & 82 & & 1 & & 177 & $0.469 \pm 0.033$ & \\
\hline & $\mathrm{HL} \times \mathrm{HL}$ & 9 & 9 & 78 & 15 & 119 & 9 & 1 & 231 & $0.593 \pm 0.015$ & $0.144 \pm 0.019$ \\
\hline & $\mathrm{LH} \times \mathrm{LH}$ & 8 & 8 & 69 & 13 & 111 & 5 & 1 & 207 & $0.537 \pm 0.067$ & $0.123 \pm 0.035$ \\
\hline & $\mathrm{L} \times \mathrm{L}$ & 7 & 6 & 85 & 7 & 69 & 5 & & 172 & $0.449 \pm 0.032$ & $0.101 \pm 0.026$ \\
\hline
\end{tabular}

B-TR, B transmission rate. 
by the total number of plants scored. It should be noted that the selected character ' $\mathrm{B}$ transmission rate' is not measured in the individuals themselves, but in their progenies. Therefore, B-TR in both $\mathrm{HL}$ and $\mathrm{LH} \mathrm{F}_{1}$ hybrids is estimated in $\mathrm{HL} \times \mathrm{HL}$ and $\mathrm{LH} \times \mathrm{LH}$ crosses, respectively.

The mean B-TR varies between the different types of cross, $\mathrm{H} \times \mathrm{H}$ being the highest value and $\mathrm{L} \times \mathrm{L}$ the lowest. It is important to determine if the $\mathrm{HL}$ and $\mathrm{LH} \mathrm{F}_{1}$ hybrids show dominance or if they behave as intermediates. To test whether the observed distribution of B chromosomes in the progenies of $\mathrm{HL} \times \mathrm{HL}$ and $\mathrm{LH} \times \mathrm{LH}$ is intermediate between $\mathrm{H} \times \mathrm{H}$ and $\mathrm{L} \times \mathrm{L}$ (null hypothesis), the weighted distribution between $\mathrm{H} \times \mathrm{H}$ and $\mathrm{L} \times \mathrm{L}$ was calculated (68.95 of $0 \mathrm{~B}$ and 94.84 of $2 \mathrm{~B}$ ) and compared to that observed in $\mathrm{HL} \times \mathrm{HL}$ and in $\mathrm{LH} \times \mathrm{LH}$ with a $\chi^{2}$ contingency test. In both cases the differences were nonsignificant $(P=0.98$ and $P=0.57$, respectively), whereas the weighted distribution was significantly different from both $\mathrm{H} \times \mathrm{H}$ and $\mathrm{L} \times \mathrm{L}$ distributions ( $P=0.003$ and $P=0.04$, respectively).

It is interesting to note that the variance of the character was low in the $\mathrm{F}_{1}$ hybrids and in the lines crossed to obtain them $(V=0.002, V=0.007, V=0.007$ and $V=0.009$ in $\mathrm{HL}, \mathrm{LH}, \mathrm{H}$ and $\mathrm{L}$, respectively). In contrast, the variance of the character in the native population was one order of magnitude higher $(V=0.063)$. This indicates that the $\mathrm{F}_{1}$ is remarkably uniform, as expected for an $F_{1}$ between two homozygous lines.

Table 1 also shows the results of $2 \mathrm{~B} \times 2 \mathrm{~B}$ crosses made in Madrid. If the two Bs had a regular meiotic segregation during megasporogenesis, $2 \mathrm{~B}$ plants should always transmit $1 \mathrm{~B}$, because it has been reported that $\mathrm{B}$ nondisjunction does not occur on the female side (Randolph, 1941; reviewed in Jones \& Rees, 1982). Therefore, as $2 \mathrm{~B}$ plants transmit $0 \mathrm{~B}$ and $2 \mathrm{~B}$ male gametes in nearly all cases (upper part of Table 1), the expected progeny in $2 \mathrm{~B} \times 2 \mathrm{~B}$ crosses consists of plants carrying only odd $\mathrm{B}$ numbers: $1 \mathrm{~B}$ and $3 \mathrm{~B}$ at high frequency, and less than $1 \% 5 \mathrm{~B}$ plants. However, unexpected 0, 2 and 4B plants were obtained, which demonstrates that irregularities occur at female gametogenesis, producing $0 \mathrm{~B}$ and $2 \mathrm{~B}$ female gametes.

The frequency of unexpected progeny is shown in the last column of Table 1. One-way ANOvA showed that differences between the four types of crosses were nonsignificant $\left(F_{3,29}=1.45, P=0.25\right)$.

In $2 \mathrm{~B} \times 2 \mathrm{~B}$ crosses, we cannot estimate male $\mathrm{B}$ transmission rate accurately with the available data, because it is not possible to determine if the two Bs of the $2 \mathrm{~B}$ progeny come from the male or the female gametes. To avoid this problem partially, we calculated the minimum estimate of male B-TR, dividing the number of plants carrying 3 or more Bs by the total number of plants of the progeny, assuming that all 2B plants received the Bs from the female gamete.

It is evident that the mean B-TR varied between the four types of $2 \mathrm{~B} \times 2 \mathrm{~B}$ crosses, $\mathrm{H} \times \mathrm{H}$ having the highest value and $\mathrm{L} \times \mathrm{L}$ the lowest. To test whether the observed B distribution in the progenies of $\mathrm{HL} \times \mathrm{HL}$ and $\mathrm{LH} \times \mathrm{LH}$ was intermediate between $\mathrm{H} \times \mathrm{H}$ and $\mathrm{L} \times \mathrm{L}$, the weighted distribution between $\mathrm{H} \times \mathrm{H}$ and $\mathrm{L} \times \mathrm{L}$ was calculated $(3.13$ of $0 \mathrm{~B}, 58.6$ of $1 \mathrm{~B}, 9.29$ of $2 \mathrm{~B}$, 129.3 of $3 \mathrm{~B}$ and 6.15 of $4+5 \mathrm{~B}$ ) and compared to that observed in HL $\times$ HL and $\mathrm{LH} \times \mathrm{LH}$ using a $\chi^{2}$ contingency test. In both cases the differences were nonsignificant $(P=0.15$ and $P=0.25$, respectively), whereas the weighted distribution was significantly different from both $\mathrm{H} \times \mathrm{H}$ and $\mathrm{L} \times \mathrm{L}$ distributions $(P=0.03$ and $P<0.001$, respectively).

A two-way ANOva was made comparing the mean B-TRs shown in Table 1 (dependent variable) with the genotype of the crosses $(\mathrm{H} \times \mathrm{H}, \mathrm{HL} \times \mathrm{HL}, \mathrm{LH} \times \mathrm{LH}$ or $\mathrm{L} \times \mathrm{L})$ and the presence/absence of $\mathrm{Bs}$ in the female parent $(0 \mathrm{~B} \times 2 \mathrm{~B}$ or $2 \mathrm{~B} \times 2 \mathrm{~B}$ crosses $)$ as factors. Only the genotype of the cross had a highly significant effect $\left(F_{3,50}=51.06, P<0.0001\right)$, whereas the presence of Bs in the female parent and the interaction were nonsignificant $\left(F_{1,50}=3.14, P=0.082 ; F_{3,50}=1.54, P=0.214\right.$, respectively).

In addition, we performed a Scheffé post-hoc test, which showed that the mean B-TR in HL $\times$ HL did not differ from that of $\mathrm{LH} \times \mathrm{LH}$, whereas both were significantly different from that of $\mathrm{H} \times \mathrm{H}$ and $\mathrm{L} \times \mathrm{L}$. This is a second way to see that HL and LH hybrids behave as intermediate types.

Table 2 shows the results obtained in the $0 \mathrm{~B} \times 2 \mathrm{~B}$ and $2 \mathrm{~B} \times 2 \mathrm{~B}$ crosses made in Buenos Aires. A two-way ANOvA was made with $\mathrm{B}-\mathrm{TR}$ as dependent variable and the genotype of the crosses $(\mathrm{H} \times \mathrm{H}$ or $\mathrm{L} \times \mathrm{L})$ and the presence/absence of $\mathrm{Bs}$ in the female parent $(0 \mathrm{~B} \times 2 \mathrm{~B}$ or $2 \mathrm{~B} \times 2 \mathrm{~B}$ crosses) as factors. As in the previous case only the genotype had a highly significant effect $\left(F_{1,27}=41.9\right.$, $P<0.0001$ ), whereas both the presence/absence of Bs in the female parent and the interaction were nonsignificant $\left(F_{1,27}=0.051, P=0.823 ; F_{1,27}=0.018, P=0.893\right.$, respectively).

The crosses made in Buenos Aires and Madrid were compared by a three-way ANOvA. The dependent variable was B-TR, and the factors were the genotype of the crosses $\left(\mathrm{H} \times \mathrm{H}\right.$ or $\mathrm{L} \times \mathrm{L} ; \quad F_{1,53}=112.76$, $P<0.0001)$; the presence of $\mathrm{Bs}$ in the female parent $\left(0 \mathrm{~B} \times 2 \mathrm{~B} \quad\right.$ or $\left.2 \mathrm{~B} \times 2 \mathrm{~B} ; \quad F_{1,53}=0.21, \quad P=0.648\right) ; \quad$ and the locality (Buenos Aires or Madrid; $F_{1,53}=1.42$, $P=0.239$ ). The interactions were nonsignificant in all cases (interaction genotype $\times$ female parent, $F_{1,53}=0.63$, $P=0.430$; interaction genotype $\times$ locality, $F_{1,53}=3.10$, $P=0.084$; interaction female parent $\times$ locality, $F_{1,53}=$ 
Table $2 \mathrm{~B}$ transmission in $0 \mathrm{~B} \times 2 \mathrm{~B}$ and $2 \mathrm{~B} \times 2 \mathrm{~B}$ maize crosses made in Buenos Aires

\begin{tabular}{|c|c|c|c|c|c|c|c|c|c|c|}
\hline \multirow[b]{2}{*}{ Type of cross } & & \multirow{2}{*}{$\begin{array}{l}\text { No. of } \\
\text { crosses }\end{array}$} & \multicolumn{6}{|c|}{ No. of Bs in the progeny } & \multirow{2}{*}{$\begin{array}{l}\text { Mean male } \\
\mathrm{B}-\mathrm{TR} \pm \mathrm{SE}\end{array}$} & \multirow{2}{*}{$\begin{array}{l}\text { Unexpected } \\
\text { progeny } \\
(\text { mean } \pm \text { SE })\end{array}$} \\
\hline & & & 0 & 1 & 2 & 3 & 4 & Total & & \\
\hline \multirow[t]{2}{*}{$0 \mathrm{~B} \times 2 \mathrm{~B}$} & $\mathrm{H} \times \mathrm{H}$ & 8 & 56 & & 141 & & & 197 & $0.711 \pm 0.038$ & \\
\hline & $\mathrm{L} \times \mathrm{L}$ & 8 & 107 & & 97 & & & 204 & $0.472 \pm 0.044$ & \\
\hline \multirow[t]{2}{*}{$2 \mathrm{~B} \times 2 \mathrm{~B}$} & $\mathrm{H} \times \mathrm{H}$ & 7 & 2 & 47 & 5 & 121 & 7 & 182 & $0.725 \pm 0.028$ & $0.074 \pm 0.016$ \\
\hline & $\mathrm{L} \times \mathrm{L}$ & 8 & 6 & 96 & 3 & 86 & 7 & 198 & $0.475 \pm 0.036$ & $0.082 \pm 0.019$ \\
\hline
\end{tabular}

B-TR, B transmission rate.

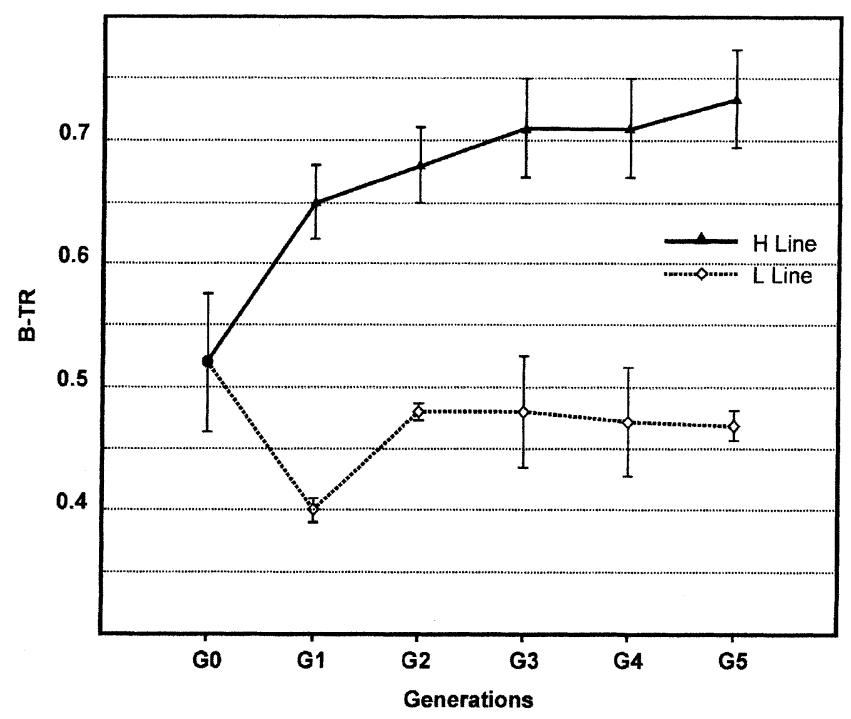

Fig. 1 Results of the selection process for high (H) and low (L) male $\mathrm{B}$ transmission rate (B-TR) along five generations (G1-5) in the native race Pisingallo $(\mathrm{G} 0)$ of maize.

$0.67, P=0.418$; interaction genotype $\times$ female parent $\times$ locality, $\left.F_{1,53}=1.63, P=0.207\right)$.

The result of the whole selection process is shown in Fig. 1. Data of the native Pisingallo population $(\mathrm{G} 0)$ and G1 were reported by Rosato et al. (1996). G2 and G3 were reported by Chiavarino et al. (1998) and G4 and G5 are reported in the present paper. B-TR values were significantly different between the $\mathrm{H}$ and $\mathrm{L}$ lines in every generation. Regression of G1 to G5 was calculated, and the slope was significant in the $\mathrm{H}$ line $(b=0.020 \pm 0.01$, $P=0.031)$ and nonsignificant in the $\mathrm{L}$ line $(b=0.013 \pm$ $0.009, P=0.078)$. It seems therefore that more selection gain in the $\mathrm{H}$ line might be expected in further generations, whereas this is not so in the $\mathrm{L}$ line.

\section{Discussion}

The process of selection for $\mathrm{H}$ or $\mathrm{L}$ B-TR in maize was designed to answer the question of how the polymorphism for B chromosomes is genetically controlled in maize. As it was stated in the introduction, there are three main factors influencing the polymorphism: (i) B nondisjunction at the second pollen mitosis; (ii) preferential fertilization by the sperm nucleus carrying the Bs; and (iii) prevention of the meiotic B loss. Our selection experiments provide insights into the three items.

\section{(i) B nondisjunction}

Carlson (1997) pointed out that B-A translocations have been extensively used in experiments to study maize $\mathrm{B}$ chromosomes and, consequently, the B has been almost always studied in the translocated form. However, important features of the $\mathrm{B}$ chromosome are different in the native and translocated forms. For example, variation in B nondisjunction frequency was described by Rusche et al. (1997) using a molecular probe to detect the presence, location and frequency of B chromosomes in interphase nuclei of pollen grains. These authors found, in the $T B-10 \mathrm{~L} 18 \mathrm{~B}-\mathrm{A}$ translocation, that nondisjunction of the $\mathrm{B}$ centromere occurred at an average frequency of $56.6 \%$. This is consistent with genetic studies using the same B-A translocation, where deletions created by the translocation breakpoints were used to establish the region involved in the nondisjunction process (Lin, 1978, 1979). In contrast, our results, obtained by scoring for B number in hundreds of plants, show that the native $\mathrm{B}$ undergoes nondisjunction in $100 \%$ of the cases because in $0 \mathrm{~B} \times 2 \mathrm{~B}$ crosses not a single $1 \mathrm{~B}$ plant was found. From our present results it can be concluded that the behaviour of the native $\mathrm{B}$ during gametogenesis is consistently repeatable, almost always producing $0 \mathrm{~B}$ and $2 \mathrm{~B}$ sperm nuclei.

As there is no variation for the character ' $\mathrm{B}$ nondisjunction at second pollen mitosis' in the native race studied, it is not possible to determine its genetic control by selection methods. In all probability, the chromosome regions controlling B nondisjunction described by Carlson (1978) and Carlson \& Chou (1981) are fixed in the native race Pisingallo. 


\section{(ii) and (iii) Preferential fertilization and prevention of meiotic $B$ loss}

The variation observed in the selected character ' $\mathrm{B}$ transmission rate', is undoubtedly due to variation in preferential fertilization. This conclusion is based on two observations. (i) Chiavarino et al. (1997) reported that in $2 \mathrm{~B}$ plants the Bs formed bivalents in about $90 \%$ of the metaphase I cells, irrespective of their $\mathrm{H}$ or $\mathrm{L}$ status and the generation of selection studied. On the other hand, the number of micronuclei at the tetrad stage was lower than $5 \%$ in all cases. It was concluded that the differential $\mathrm{B}$ transmission on the male side was not due to a differential $\mathrm{B}$ gain or loss at male meiosis. (ii) Since a $100 \%$ B nondisjunction produces only $0 \mathrm{~B}$ and $2 \mathrm{~B}$ sperm nuclei in a $1: 1$ ratio, the high or low B-TR needs to be achieved in a later stage, most likely by differential fertilization success of both sperm nucleus types.

Considering the results of the selection process carried out for the character high or low B-TR during five consecutive generations (Fig. 1), it can be observed firstly, that the L line is characterized by a Mendelian B-TR (0.5), whereas the $\mathrm{H}$ line shows a higher than Mendelian B-TR (about 0.7). Secondly, that all detectable selection gain in the $\mathrm{L}$ line, and most of that of the $\mathrm{H}$ line, was obtained in the first generation of selection. The simplest explanation for this result is that a single major gene with two alleles $(H$ and $L)$ is controlling the selected character. Thus, most plants obtained in the first generation were the two $\mathrm{HH}$ and $L L$ homozygotes. This conclusion is also consistent with the low variance of the selected character in both $\mathrm{F}_{1} \mathrm{HL}$ and $\mathrm{LH}$ hybrids, as expected in a uniform $\mathrm{F}_{1}$ between homozygous lines. The similarity between the results obtained in Madrid and Buenos Aires, which found no detectable environmental effect, reinforces the same conclusion.

Chiavarino et al. (1998) demonstrated that, in $0 \mathrm{~B} \times 2 \mathrm{~B}$ crosses, male $\mathrm{B}-\mathrm{TR}$ depended on the $0 \mathrm{~B}$ female parent, irrespective of the Bs. It was therefore concluded that the gene/genes controlling B-TR are located on the A chromosomes. These results also indicate that the genotype of the $0 \mathrm{~B}$ female determines the rate at which the egg cell is fertilized by the sperm nucleus carrying the Bs. Therefore, a $0 \mathrm{~B}$ female parent of the $\mathrm{H}$ genotype preferentially selects the $2 \mathrm{~B}$ sperm to fertilize the egg; in contrast, the $0 \mathrm{~B} \mathrm{~L}$ female does not select any sperm nucleus, resulting in a Mendelian B-TR.

In the present work, significant differences between $0 \mathrm{~B} \times 2 \mathrm{~B}$ and $2 \mathrm{~B} \times 2 \mathrm{~B}$ crosses were not found. This indicates that male B-TR is not affected by the presence of Bs in the egg-cell, which is in agreement with the hypothesis.
The intermediate B-TR found in the HL and $\mathrm{LH}$ hybrids reported in this work further supports this conclusion and strongly suggests that an HL or LH $0 \mathrm{~B}$ hybrid used as female, will produce $50 \%$ of $\mathrm{H}$ and $50 \%$ of $\mathrm{L}$ egg-cells. The $\mathrm{L}$ egg cell will be fertilized by the $0 \mathrm{~B}$ or $2 \mathrm{~B}$ sperm at random, whereas the $\mathrm{H}$ egg cell will be preferentially fertilized by the $2 \mathrm{~B}$ sperm. The overall result will be an intermediate $\mathrm{B}-\mathrm{TR}$ between the $\mathrm{H}$ and $\mathrm{L}$ lines. Our hypothesis is that the gene controlling B-TR acts in the egg cell at the haploid level during fertilization.

Cytoplasmic maternal effects can be discarded. If the high or low B-TRs were due to a maternal effect, HL hybrids would show H B-TR and LH ones would show L B-TR; however, HL and LH hybrids behaved similarly.

The main aim of investigation into variation in B-TR is to understand the genetic basis of B polymorphism and, consequently, its influence on genome evolution. $\mathrm{B}$ chromosome evolution has been recently reviewed by Camacho et al. (2000), who discuss the equilibrium models of B evolution for heterotic and parasitic Bs (Jones, 1985; Shaw \& Hewitt, 1990; Bougourd et al., 1995; Bougourd \& Jones, 1997), and further develop the nonequilibrium model based mainly on the B chromosome system of the grasshopper Eyprepocnemis plorans, where the parasitic Bs have been neutralized by the A genome (Camacho et al., 1997a, b; Zurita et al., 1998). The nonequilibrium model of long-term evolution of $\mathrm{B}$ chromosomes is considered to be the outcome of selection on the host genome to eliminate B chromosomes or suppress their effects and on the B chromosome's ability to escape through the generation of new variants (Camacho et al., 2000).

Our results are in agreement with Camacho's hypothesis because an $\mathrm{H}$ allele promoting the transmission of the $\mathrm{B}$ is compatible with $\mathrm{A}$ and $\mathrm{B}$ chromosome coevolution. Our hypothesis is that the main function of the gene controlling B-TR that we have selected, is not to determine $\mathrm{B}$ preferential fertilization rate. On the contrary, we think that this gene, located on the As, is involved in the normal fertilization process, but that the Bs have an opportunistic behaviour, taking advantage of the $\mathrm{H}$ function to increase their own transmission. The $L$ allele could be the response of the host genome to get rid of the B effects. Therefore, our proposal is that maize Bs have parasitic behaviour, using the characteristics of the normal maize fertilization process to generate the necessary drive to invade and persist in populations, promoting their own transmission. The $H$ allele, located on the A chromosomes and probably involved in the normal process of gamete fertilization, allows B chromosome accumulation (and hence B chromosome attack), and another allele in the same

(C) The Genetics Society of Great Britain, Heredity, 86, 743-748. 
gene $(L)$ is a mutation suppressing B accumulation (thus providing A chromosome defence). The existence of the $H$ and $L$ alleles as a polymorphic system of attack and defence between $\mathrm{A}$ and $\mathrm{B}$ chromosomes is a clear example of the coevolution of genome conflict as reviewed in Frank (2000).

\section{Acknowledgements}

We thank Dr J.P.M. Camacho for his valuable comments to the manuscript. We also thank Dr C.A. Naranjo for his suggestions and critical comments. A.M. Chiavarino and M. Rosato are postdoctoral grant holders of the CONICET (Argentina). P. Rosi is a predoctoral grant holder of the University of Buenos Aires. This work was supported by grant 98-0678 of the DGES of Spain and by the Agencia Nacional de Promoción Científica y Tecnológica, CONICET, Argentina.

\section{References}

BECKETT, J. B. 1982. An additional mechanism by which B chromosomes are maintained in maize. J. Hered., 73, 29-34.

BOUGOURD, S. M. AND JONES, R. N. 1997. B chromosomes: a physiological enigma. New Phytol., 137, 43-54.

BOUGOURD, S. M., PlOWMAN, A. B., PONSFORD, N. R., ELIAS, M. L. ET AL. 1995. The case for unselfish B chromosomes: evidence from Allium schoenoprasum. In: Brandham, P. E. and Bennett, M. D. (eds) Kew Chromosome Conference IV, pp. 21-34. Royal Botanic Gardens, Kew, UK.

CAMACHO, J. P. M., CABRERO, J., LÓPEZ-LEÓN, M. D. AND SHAw, M. W. 1997a. Evolution of a near-neutral B chromosome. In: Henriques-Gil, N., Parker, J. S. and Puertas, M. J. (eds) Chromosomes Today, vol. 12, pp. 301-318. Chapman \& Hall, London.

CAMACHO, J. P. M., SHAW, M. W., LÓPEZ-LEÓN, M. D., PARDO, M. C. ET AL. 1997b. Population dynamics of a selfish B chromosome neutralized by the standard genome in the grasshopper Eyprepocnemis plorans. Am. Nat., 149, 1030-1050.

CAMACHO, J. P. M., SHARBEL, T. F. AND BEUKEBOOM, L. W. 2000. B-chromosome evolution. Phil. Trans. R. Soc. B, 355, 163-178.

CARLSON, W. R. 1969. Factors affecting preferential fertilization in maize. Genetics, 62, 543-554.

CARlson, w. R. 1978. The B chromosome of corn. Ann. Rev. Genet., 16, 5-23.

CARLSON, W. R. 1997. Pollen competition effects in crosses of the B-A translocation, TB-9SB ${ }^{1}$. Maydica, 42, 121-126.
CARLSON, W. R. AND CHOU, T. S. 1981. B chromosome nondisjunction in corn: control factors near the centromere. Genetics, 97, 379-389.

CARLSON, W. R. AND ROSEMAN, R. 1992. A new property of the maize B chromosome. Genetics, 131, 211-223.

ChIAVARINo, A. M., Rosato, M., Rosi, P., NARANJo, C. A. ET $A L$. 1997. B chromosomes in native races of maize from Argentina. III. Selection of high and low transmission genotypes and meiotic behavior of Bs. Maize Genet. Coop. Newsl., 71, 48-49.

ChiAvarino, A. M., ROSATO, M., ROSI, P., POGGIO, L. ET AL. 1998. Localization of the genes controlling B chromosome transmission rate in maize (Zea mays ssp. mays, Poaceae). Am. J. Bot., 85, 1581-1585.

FRANK, S. A. 2000. Polymorphism of attack and defense. Trends Ecol. Evol., 15, 167-171.

JONES, R. N. 1985. Are B chromosomes "selfish"? In: CavalierSmith, T. (ed.) The Evolution of Genome Size, pp. 397-425. John Wiley \& Sons Ltd., London.

JONES, R. N. AND REES, H. 1982. B-Chromosomes. Academic Press, London.

LIN, B. Y. 1978. Regional control of nondisjunction of the B chromosome in maize. Genetics, 90, 613-627.

LIN, B. Y. 1979. Two new B-10 translocations involved in the control of nondisjunction of the B chromosome in maize. Genetics, 92, 930-945.

RANDOLPH, L. F. 1941. Genetics characteristics of the B chromosomes in maize. Genetics, 26, 608-631.

ROMAN, H. 1947. Mitotic nondisjunction in the case of interchanges involving the B-type chromosome in maize. Genetics, 32, 391-409.

Roman, H. 1948. Directed fertilization in maize. Proc. Natl. Acad. Sci. U.S.A., 34, 36-42.

rosato, M., ChiAvarino, A. M., NARANJo, C. A., PUERTAS, M. J. ET AL. 1996. Genetic control of B chromosome transmission rate in Zea mays ssp. mays (Poaceae). Am. J. Bot., 83, 11071112.

rosato, M., ChiAvarino, A. M., NARANJo, C. A., CÁMARAHERNÁNDEZ, J. ET AL. 1998. Genome size and numerical polymorphism for the $\mathrm{B}$ chromosome in races of maize (Zea mays ssp. mays (Poaceae). Am. J. Bot., 85, 168-174.

RUSCHE, M. L., MOGENSEN, H. L., SHI, L., KEIM, P. ET AL. 1997. B chromosome behavior in maize pollen as determined by a molecular probe. Genetics, 14, 1915-1921.

SHAW, M. W. AND HEWITT, G. M. 1990. B chromosomes, selfish DNA and theoretical models: where next?. In: Futuyma, D. and Antonovics, J. (eds) Oxford Surveys in Evolutionary Biology, vol. 7, pp. 197-223. Oxford University Press, Oxford. ZURITA, S., CABRERO, J., LÓPEZ-LEÓN, M. D. AND CAMACHO, J. P. M. 1998. Polymorphism regeneration for a neutralized selfish B chromosome. Evolution, 52, 274-277. 